\title{
Factors affecting satisfaction and loyalty to online group buying
}

Determinants of loyalty to online group buying

Jorge Mazza Garcia

Centro Universitário ENIAC, São Paulo, Brazil

Otávio Bandeira De Lamônica Freire

Department of Marketing, Universidade de São Paulo, São Paulo, Brazil

Eduardo Biagi Almeida Santos

Diretoria de Ciências Gerenciais, Universidade Nove de Julho,

São Paulo, Brazil, and

Josmar Andrade

Department of Marketing, Universidade de São Paulo, São Paulo, Brazil

\begin{abstract}
Purpose-In 2008, a phenomenon emerged in online retail that attracted the attention of many people, creating a new virtual model of commerce. This phenomenon was called online group buying and arrived in Brazil in 2010. The purpose of this study was to identify the factors that affect satisfaction and loyalty to group buying sites.

Design/methodology/approach - Through structural equation modeling, the relationships between the attractiveness of discount rates, service quality, popularity, online brand image, antecedent word of mouth (WOM), creativity and trust in relation to consumer general satisfaction, declared loyalty, repurchase intention and positive WOM were observed. A total of 727 valid questionnaires were collected from online group buyers to test the 11 hypotheses proposed in this study.

Findings - The main contribution of this study was that it identified the strong influence of service quality, popularity and online brand image on consumer general satisfaction, and the influence of service quality, trust and general satisfaction on repurchase intention. It also identified the influence of trust, creativity and general satisfaction on declared loyalty, and finally, the influence of trust and general satisfaction on positive WOM.

Research limitations/implications - Because of the extensive and robust model, other statistical interactions among the constructs were gauged. It is possible that new structures and paths for alternative models can be proposed in the future with the inclusion of new relationships not analyzed in the present study. Furthermore, future studies should consider testing the generated model in other countries, as the particular features of collective purchasing in Brazil should be taken into account.

Practical implications - In addition to being concerned with the attractiveness of discounts, marketing managers of group buying sites should concentrate their efforts on strengthening perceived quality, image, trust and the creativity of the site to ensure customer loyalty.

Social implications - The online group buying business model that was established in Brazil differs significantly from the American and European models. As many online group buying studies have been conducted in these markets, Brazilian consumers will enjoy substantial gains in the quality of the service provided by collective purchasing sites through the development of actions that focus on improving the factors that affect these consumers.
\end{abstract}

(C) Jorge Mazza Garcia, Otávio Bandeira De Lamônica Freire, Eduardo Biagi Almeida Santos and Josmar Andrade. Published in Revista de Gestão. Published by Emerald Publishing Limited. This article is published under the Creative Commons Attribution (CC BY 4.0) license. Anyone may reproduce, distribute, translate and create derivative works of this article (for both commercial and non-commercial purposes), subject to full attribution to the original publication and authors. The full terms of this license may be seen at: http://creativecommons.org/licences/by/4.0/legalcode

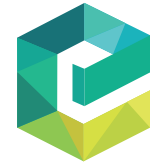

Revista de Gestão Vol. 27 No. 3, 2020 pp. $211-228$ Emerald Publishing Limite e-ISSN: $2177-8736$ p-ISSN: $1809-2276$ DOI 10.1108/REGE-02-2018-0037 
REGE 27,3
Originality/value - The originality of this study lies in the development of a single model that tests a set of factors gauged separately in other studies related to online purchase behavior in a broader perspective.

Keywords Group buying, Satisfaction, Loyalty, Consumer behavior, Structural equation modeling Paper type Research paper

\section{Introduction}

The rapid growth of information technology on the Internet and in e-commerce has led to the creation of various business opportunities. The Internet influences people through features such as communication, entertainment, social activities and choices of products (Shiau \& luo, 2012).

This situation leads to the possibility of group negotiations known as collective purchasing (Benazzi \& Pedra, 2011). Group buying is part of electronic commerce, selling products and services at below-market prices (Lim, 2019). This business model stipulates a minimum number of buyers to guarantee a special offer. If this number of buyers is not achieved, the money is refunded to those who had already paid for the offer. Discounts vary significantly (from 50 to $90 \%$ of the normal price of products or services). Special offers have a time limit that varies from 24 to $48 \mathrm{~h}$, with a timer on the screen counting down to the end of the offer.

The group buying business model has attracted attention form the market in a number of countries around the world, such as the United States, China, Taiwan, Canada, Russia, Germany and Brazil (Chiu, Chen, Du, \& Hsu, 2018; Lin, Yen, Wang, \& Yeh, 2018). In China, over a quarter of the country's internet users - more than $180 \mathrm{~m}$ people - had already used group buying sites in 2015 (Xiao, 2018). In the United States, it was estimated that the turnover of this sector in 2015 was over four billion dollars (Lin, Yen, Wang, \& Yeh, 2018). Peixe Urbano, the largest player in the market, with over $31.5 \mathrm{~m}$ users in the country and over $20.5 m$ in the rest of Latin America (Mercado \& Consumo, 2019), grew over 40\% in 2016 and more than $30 \%$ in 2017 (Exame, 2018).

However, it is important to highlight that increasing competition on a large scale has created difficulties for companies. In China, the mortality rate was over $70 \%$ in 2015 (Xiao, 2018). In the United States, 170 of the 530 group buying sites were taken over or went bankrupt in 2011 (Lin, Yen, Wang, \& Yeh, 2018). A number of internal and external factors can lead to the failure of group buying sites. One of these critical factors is not considering the reasons why users visit a site, use it and continue to purchase coupons or simply stop buying and abandon the platform.

Diverse studies have sought a deeper scientific understanding of the phenomenon. Their contributions include adopting new group buying formats, with the addition of affective variables (Ieva, de canio, \& Ziliani, 2018; Chiu, Chen, Du, \& Hsu, 2018) and an interpretative view of uses and gratifications that motivate online group buying (Xiao, 2018). They also involve the interaction between personality traits and cultural orientation as antecedents of group buying intention (Han \& Kim, 2019) and analyses of rewards and their effects on customer loyalty (Chiu, Chen, Du, \& Hsu, 2018), as well as responses from consumers to service failure on group buying sites (Lin, Yen, Wang, \& Yeh, 2018). Frederico, Teixeira, Gahni, \& Andrade (2017) investigated the effect of both service quality and quality of the site on loyalty to group buying sites in the Brazilian context. Nevertheless, the literature has yet to provide a model that simultaneously considers variables related to the quality of the relationship and interaction allied with the attractiveness of a special offer, the creativity of the site and brand image. This way, marketing managers could be provided with a broader vision of group buying behavior, under an integrative perspective, that considers both utilitarian/hedonic aspects, as well as more concrete service-related and abstract brandrelated aspects. 
In Brazil, the group buying operations were launched differently from other countries. While a relationship network, with discussions of the product or service through the site itself prior to purchase is generated, in Brazil, the group buying user purchases through a more individual process, with little or no interaction with other users. The proposed research problem in this study is to discover, in the Brazilian scenario, the determinants of satisfaction and loyalty on group buying sites. In particular, this study intends to analyze the impact of the attractiveness of discount rates, service quality, popularity, online brand image, antecedent word of mouth (WOM), trust and creativity on satisfaction and loyalty on purchases from group buying sites.

\section{Theoretical framework}

In 2018, the electronic market grew 17.9\% compared with the previous year, and $58 \mathrm{~m}$ Brazilians made at least one online purchase. Of these consumers, $10 \mathrm{~m}$ made their first online purchase, showing an active growth in purchases in the digital environment (E-Bit, 2019). The significant growth of electronic commerce, also known as e-commerce, is an alternative for customers to make purchases quickly and practically, without leaving the house. However, all this growth has to be supported by good presale, sale and postsale strategies. Customers are becoming more and more demanding regarding delivery deadlines and the security and reliability of e-commerce (Coelho Oliveira \& Alméri, 2013).

Several changes in technology and, consequently, in forms of consumption, lead to an increase of the number of purchase options on the Internet. Group buying has led to much lower prices than normally practiced on the market (Mendes Filho, Jorge, \& De SenaJúnior, 2016). Therefore, online group buying is an effective form of commercialization. When using this resource, customers enjoy significant discounts on products and services. Not only does this satisfy customer demand but it also helps sellers to find new ways to leverage product sales and open up new business models. In other words, all parties benefit from these transactions (Liao et al., 2012; Lim, 2019).

However, it has been observed that discounts are not the only factors that influence consumers when visiting these sites (Lim, 2019). Perceived risk and trust are also at play (Dias, Santos, Martins, \& Isabella, 2014).

Group buying is defined as occurring when products and services are made available at reduced prices in such a way that it is possible to offer a differentiated discount for a limited time compared with the standard applied by the store (Lim, 2019). Therefore, group buying sites seek to create value for all those involved in the transaction. Decision-making in group buying is mainly based on convenience, low prices, trust in quality standards and consumer habits (Coulter \& Roggeveen, 2012; Dias, Santos, Martins, \& Isabella, 2014; Lim, 2019). Group buying spreads and makes people purchase quickly and often impulsively (Reck \& Basso, 2018). It enables the creation of an online network for discussing purchases, where consumers get in touch with other customers before making purchases. Therefore, group buying could mean a possibility to interact with other customers and share information before making purchases (Ku, 2012).

\subsection{General satisfaction}

When a group buying site user confirms his/her order, he/she analyzes the purchasing process as a whole and attributes a positive or negative feeling to it. This feeling is the result of the entire purchasing process - for instance, of a coupon purchase and use - and is called satisfaction (Zhang et al., 2013).

General Satisfaction is a strong antecedent variable in the construction of customer loyalty (Oliver, 1997; Dick \& Basu, 1994; Laran \& Espinoza, 2004). There is a relationship between customer satisfaction and declared loyalty, repurchase intention and positive WOM
Determinants of loyalty to online group buying 
REGE 27,3

\section{4}

(Parasuraman, Zeithaml, \& Malhotra, 2006; Zhang et al., 2013). Nevertheless, the constitution of a customer's satisfaction will depend on a number of factors that precede this final evaluation. For instance, Abdeldayem (2010) proposed and tested a model that considers both online channel and web-store traits as antecedents of satisfaction with online shopping, moderated by consumer traits. The model is robust in terms of explaining online shopping satisfaction and the majority of the variables can also be used to explain group buying behavior concerning the seek for satisfaction. But there are some particularities that will be addressed by this study.

\subsection{Loyalty}

Loyalty is a strong commitment from a consumer to repurchase a product or service in the future without considering the marketing strategies and efforts that might influence consumer behavior (Oliver, 1997).

The online purchase scenario is characterized by fierce competition, as consumers have almost instant access to large amounts of information, which heightens competition further still and reduces consumer loyalty (Frederico, Teixeira, Ghani \& Andrade, 2017). Attitudinal loyalty is structured in three dimensions: repurchase intention, positive WOM and declared loyalty (Oliver, 1999; Dick \& Basu, 1994; Lopes, Hernandez, \& Nohara, 2009). It is estimated that when the consumer is satisfied with the group buying site experience, he/she will make further purchases and recommend the platform to other people, meaning that he/she will become loyal to the site.

\subsection{Repurchase intention}

Repurchase intention is a dimension of attitudinal loyalty that identifies the need to acquire a product or service again following a previous, normally positive, experience (Parasuraman, Zeithaml, \& Malhotra, 2006). Oliver (1999) claims that loyalty is a commitment to repurchase or future preference for a product, service or brand. Doney and Cannon (1997) add in their study that customers' trust in service companies can lead to a process of commitment and future purchase intentions. This commitment can lead a consumer to make new searches and acquire coupons on a group buying site.

\subsection{Positive word of mouth}

Positive WOM is a dimension of attitudinal loyalty that identifies consumer behavior in terms of speaking, commenting and propagating an experience in the negotiation of a product or service following a previous, usually positive, purchase and/or product usage (Parasuraman, Zeithaml, \& Malhotra, 2006).

Loyalty increases the likelihood that a consumer will recommend the site to acquaintances and be more resistant to offers from the competition (Srinivasan, Anderson, \& Ponnavolu, 2002; Dick \& Basu, 1994). In the context of a group buying site, clearly perceiving the service quality or even the creativity used in its design to make using the site a more involving experience can encourage users to recommend it to other people they know.

\subsection{Declared loyalty}

Declared loyalty is a dimension of attitudinal loyalty that identifies consumer behavior when it comes to self-declaring loyalty to a company, product or service following previous, usually positive, experiences (Parasuraman, Zeithaml, \& Malhotra, 2006).

From an attitudinal perspective of loyalty, consumers' attitudes to acquired products and services can influence future behavior. This can be measured by self-declared evaluations of loyalty. In the context of group buying, in addition to perceived quality, it is 
important for users to feel secure and have trust in the transaction. Only then will they declare their loyalty.

\subsection{Attractiveness of discount rates}

The attractiveness of discount rates is an important pricing strategy on group buying sites. It can be considered as the percentage of price reduction given in a special offer in the form of a coupon. Price is an important marketing element in the strategy of promoting sales and can increase sales performance in the short term and help to maintain a company's market share (Isabella et al., 2012). Group buying companies work insistently on pricing, generating collective discounts that mostly vary between $50 \%$ and $70 \%$ of the original price (Zhang et al., 2013).

Different structures of offers and discount rates have direct impacts on the influence of purchase intent, recommendations and perceived quality (Isabella et al., 2012). Consequently, they can influence the consumer's general satisfaction. Although studies have been conducted on prices, none was found specifically addressing discount rates and their relationship with satisfaction. Furthermore, no scale that measures this variable has been found.

When shopping on sites that constantly and systematically offer attractive discount rates, consumers of this kind of service tend to feel more satisfied with the purchases they make. They feel that they have gained an advantage in relation to a transaction without the differentiated conditions of a discount. Based on the assumptions presented above, Hypothesis H1 of this study was developed:

H1. The attractiveness of discount rates on a group buying site is positively associated with general satisfaction with the site.

\subsection{Service quality}

The three most commonly used scales found in the literature for measuring the quality of sites are the e-SERVQUAL, WEBQUAL and eTailQ (Hapenciuc \& Condratov, 2007). The eSERVQUAL measures customers' perceived quality of websites. The WEBQUAL scale focuses on the interface of the site and closely monitors the behavior that reusing and revisiting sites entails. Meanwhile, the eTailQ scale seeks to predict customers' judgments regarding quality and satisfaction with the site (Hapenciuc \& Condratov, 2007).

One of the features of group buying is the need to search the site quickly, given that time is an important factor with regard to special offers, especially the most attractive ones. Therefore, it is important that the site should be easy to browse and that users should feel a sense of security and that the service is facilitated by the platform. In this sense, the eTailQ service quality in Electronic Retail Scale has been firmly established and validated by several previous studies (Wolfinbarger \& Gilly, 2003). Lopes, Freire, \& Herrero (2019) tested eTailQ and ES-Qual in an online competing scale scenario. The eTailQ proved itself as the one that is best suited for the study of group buying sites.

The dimensions of service quality have a strong influence on declared loyalty, repurchase intention and positive WOM (Parasuraman, Zeithaml, \& Malhotra, 2006; Zhang et al., 2013). Quality is related to customer satisfaction, as well as retention and developing loyalty to products and services. Therefore, quality is expected to be a determining factor in the success of online retail (Wolfinbarger \& Gilly, 2003). Customers who have a positive experience and perceive the delivery of a quality service on group buying sites tend to feel generally satisfied. In this respect, the second hypothesis of this study, H2, may be stated.

H2. The service quality of a collective purchasing site is positively associated with general satisfaction with the site.
Determinants of loyalty to online group

buying 
REGE 27,3

\section{6}

Several authors have cited perceived quality as an important antecedent for consumer loyalty to a service (Parasuraman, Zeithaml, \& Berry, 1988; Dabholkar, Thorpe, \& Rentz, 1996). As they work with considerable discount rates and, consequently, lower profit margins, the companies that present their special offers and the group buying sites need to attract consumers and make them loyal customers. One of the loyalty dimensions is intention to repurchase the service based on a positive evaluation of a previous experience. It is also expected that a perception of quality will lead individuals to speak favorably of the site to people close to them and self-declare loyalty to the group buying site. This leads to Hypotheses H3a, H3b and H3c of this study:

$H 3 a$. The service quality of a group buying site is positively associated with declared loyalty to the site.

$H 3 b$. The service quality of a group buying site is positively associated to repurchase intention on the site.

$H 3 c$. The service quality of a group buying site is positively associated to positive WOM with regard to the site.

\subsection{Popularity of the site}

Popularity may be considered as the perception that many people are familiar with and use the services of a certain group buying site. This perception may be due to the number of comments regarding the service. In the literature, it has been argued that consumers tend to follow choices made by other people. A high level of popularity can lead consumers to rationalize their purchase decisions by claiming that other people also bought the same product. Moreover, sales promotions, such as coupons, can encourage loyal and occasional customers to purchase before the consumption date (Zhang et al., 2013).

Popularity increases the likelihood of customers making purchases and reduces acquisition time, and factors related to social influence, reference intensity and collective consumption increase these effects (Luo et al., 2014).

Assessing that they have made the right decision because other people are also using the same collective purchasing site can give consumers a positive feeling, affecting their general satisfaction, leading to the following hypothesis:

H4. The popularity of a group buying site is positively associated with general satisfaction with the site.

\subsection{Online brand image}

Online brand image is associated with the strength that the group buying site's publicity can generate for its advertising companies. The power of the brand's communication and its influence on consumers' decision-making suggest that strong sources of reference forge more significant and important ties in terms of satisfaction than weak sources of information (Ku, 2012). The brand image is not inherent to the technical, functional or physical concerns of the product, but rather is affected and shaped by marketing activities, context variables and characteristics of the observer (Dobni \& Zinkhan, 1990).

One of the most important elements for customer satisfaction is the establishment of a brand. A positive brand image of the site can strengthen the offers on show, reducing uncertainty and helping to build satisfaction (Kuenzel \& Halliday, 2008). In this respect, we formulated the following hypothesis:

H5. The online brand image of a group buying site is positively associated with general satisfaction with the site. 


\subsection{Antecedent word of mouth}

WOM marketing strategies are attractive because they combine overcoming the consumer's resistance with significantly lower prices and fast delivery, especially using technology, such as the Internet (Trusov, Bucklin, \& Pauwels, 2009). WOM is an important source of information for the consumer. It is formed by interpersonal communication, and it has a significant influence on product perceptions, evaluations and purchase decisions. WOM has a strong impact on the judgment of products. WOM has been shown to generate high levels of commitment, relationship and satisfaction (Ku, 2012).

WOM that precedes a purchase generates a feeling of comfort, like popularity, and can lead to general consumer satisfaction, which leads to Hypothesis H6:

H6. Consumers' antecedents of WOM regarding a group buying site are positively associated with general satisfaction with the site.

\subsection{Trust}

Trust is defined as the delegation of some elements, from one party to another, in the belief that it will live up to expectations effectively and efficiently. At this time, the consumer ceases to analyze traditional elements of rational consumer behavior and believes that the other party involved will act in a satisfactory manner, given that there is a relational commitment between the two parties (Terres, Santos, \& Alves, 2009).

According to Shiau and Luo (2012), trusting in the site means believing that it can live up to expectations. Consumers' trust in service companies can create a process of commitment and future purchase intentions (Doney \& Cannon, 1997). Based on these elements, it is suggested that in the group buying scenario, there will be the same association between trust and satisfaction, as shown in the following hypothesis:

H7. The consumer's trust in a group buying site is positively associated with general satisfaction with the site.

When people are faced with risks, trust is one of the most insightful aspects of the process. Consumers' trust in collective purchasing sites reduces the perception of risk regarding the special offers available, creating a relationship and loyalty between the parties (Shiau \& Luo, 2012).

There is a wide body of knowledge that already consolidated the relationship between trust and loyalty (Santos \& Fernandes, 2005; Matos \& Henrique, 2006; Terres, Santos, \& Alves, 2009). A user who trusts the group buying site believes that the relationship built up so far is strong and firm, which makes him/her feel safe to declare himself/herself loyal, use the platform again and recommend the site to other consumers, leading to Hypotheses H8a, H8b and $\mathrm{H} 8 \mathrm{c}$ :

$H 8 a$. The consumer's trust in a group buying site is positively associated with declared loyalty to the site.

H8b. The consumer's trust in a group buying site is positively associated with repurchase intention in relation to the site.

$H 8 c$. The consumer's trust in a group buying site is positively associated with positive WOM in relation to the site.

\subsection{Creativity of the site}

Creativity in marketing is seen when actions are planned to commercialize a product or service. It is perceived when company's strategies show a significant difference from those
Determinants of loyalty to online group

buying 
REGE 27,3

commonly practiced by their competitors (Shalley, Gilson, \& Blum, 2000; Andrews \& Smith, 1996).

Interacting with a creative group buying site is a pleasant task and, at the end of the process, the probability of customer satisfaction increases, leading to the following hypothesis:

H9. The creativity of a group buying site is positively associated with general satisfaction with the site.

Creativity generates different actions and reactions in each strategy and can make the site more easily acceptable, thus strengthening the user's feeling of loyalty (Cedrola \& Memmo, 2010), leading to Hypotheses H10a, H10b and H10c of this study:

H1Oa. The creativity of a group buying site is positively associated with declared loyalty to the site.

H1Ob. The creativity of a group buying site is positively associated with repurchase intent in relation to the site.

H1Oc. The creativity of a group buying site is positively associated with positive WOM in relation to the site.

\subsection{General satisfaction and attitudinal loyalty}

Many studies and authors have pointed to general satisfaction as an antecedent to consumer loyalty (Oliver, 1997; Dick \& Basu, 1994). In the context of group buying, a positive evaluation of the entire process of searching for coupons and purchasing leads users to believe that it is worthwhile to repurchase, remaining loyal and telling others of their positive experience on the site, leading to Hypotheses H11a, H11b and H11c:

H11a. The general satisfaction of consumers with a group buying site is positively associated with declared loyalty to the site.

H11b. The general satisfaction of consumers with a group buying site is positively associated with repurchase intention on the site.

H11c. The general satisfaction of consumers with a group buying site is positively associated with positive WOM regarding the site (see Figure 1).

\section{Research method}

In accordance with the purpose of this study, a quantitative research was conducted, using the survey method, with a questionnaire containing the 68 items to measure all the constructs proposed in the model, as well as consumer profile variables and filters. The research universe was made up of people familiar with electronic retail that had made purchases on group buying sites in the three months prior to the study. The final sample was composed of 727 valid questionnaires, a sufficient amount for the SmartPLS software for structural equation modeling, following the procedures recommended by Ringle et al. (2014). The scales used in the questionnaire are shown in Table 1.

\section{Analysis}

The final sample was made up of 399 women (55\%) and 328 men (45\%). With regard to age, 331 interviewees were aged 16-25 years (45\%), 290 were aged $26-35$ years $(40 \%)$, 77 were aged $36-45$ years $(11 \%), 24$ were aged $46-55$ years $(3 \%)$ and five were aged over 55 years $(1 \%)$. 


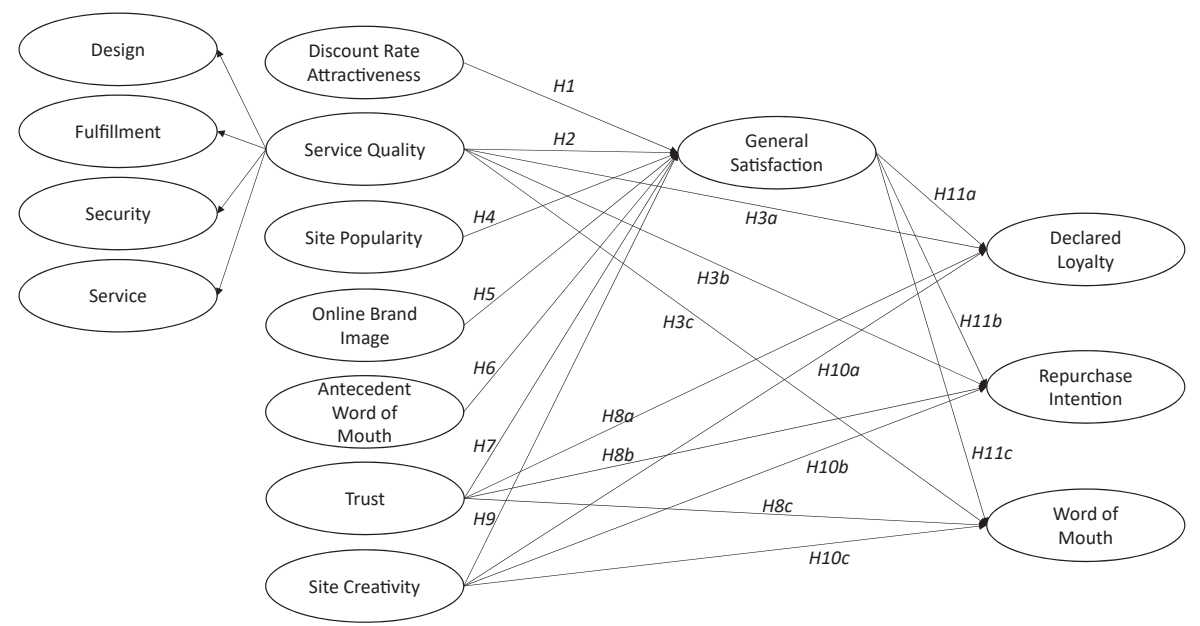

Determinants of loyalty to online group buying

Source(s): Elaborated by the authors

Figure 1. Theoretical model

\begin{tabular}{lcl}
\hline Variable & Number of items & Source \\
\hline Profile/Filter & 11 & Prepared by the authors \\
Attractiveness of discount rates & 4 & Prepared by the authors \\
Service quality & 14 & Wolfinbarger and Gilly (2003) \\
Popularity & 5 & Lam and mukherjee (2005); Bruner (2009) \\
Online brand image & 4 & Yeh and Li (2009) \\
Antecedent word of mouth & 8 & Cheung et al. (2008) \\
Trust & 6 & Odekerken-Schrode et al. (2003), \\
& & Terres, Santos and Alves (2009) \\
Creativity of the site & 4 & Zhou and George (2001) \\
Satisfaction & 9 & Bhattacherjee (2001) \\
Declared loyalty & 8 & Srinivasana, Anderson and Ponnavolu (2002) \\
Repurchase intention & 3 & Zeithaml, Berry and Parasuraman (1996) \\
Positive word of mouth & 3 &
\end{tabular}

Source(s): Elaborated by the authors

Table 1.

Operationalization of the variables

Regarding their last collective purchase, 199(27\%) people purchased food, 159(22\%) purchased health and beauty products, 99(14\%) paid for hotels and trips, 91(13\%) paid for entertainment, $78(11 \%)$ people bought products, $47(6 \%)$ purchased tickets to shows, $46(6 \%)$ paid for services and nine (1\%) spent money on healthcare.

Concerning the time that had passed since their last collective purchase, 57(8\%) interviewees stated that they had made their purchase during the week prior to completing the questionnaire, $110(15 \%)$ said it was in the last fortnight, $220(30 \%)$ people said it was a month before, $165(23 \%)$ respondents said it was two months before and $175(24 \%)$ said it was three months before taking part in the research.

With regard to the frequency of making collective purchases, $14(2 \%)$ interviewees said it was less than once a year, 51(7\%) only once a year, 197(27\%) at least once every six months, $194(27 \%)$ every three months, $121(17 \%)$ every two months, $105(14 \%)$ at least once a month, $32(4 \%)$ every fortnight and $13(2 \%)$ at least once a week. 
REGE

27,3

220

\subsection{Convergent validity}

To gauge the convergent validity of the model, the results of the average variance extracted (AVE) were observed (over 0.5), along with Cronbach's alpha (over 0.7) and composite reliability (over 0.6) (Ringle, Silva, and Bido, 2014). The adjustment was made by removing 2 measured items from the satisfaction construct. The results are shown in Table 2 and confirm the convergent validity, showing that the items observed converged to form the research constructs.

\subsection{Discriminant validity}

Discriminant validity was accessed by checking if the internal item correlations of the construct was higher than the external correlation with another construct. The adjustment was made by removing 2 items from service quality, 3 from satisfaction, 3 from trust and 2 from declared loyalty. The results are shown in Table 3 and confirm the discriminant validity, showing that all the research constructs discriminate among themselves.

\subsection{Blindfolding}

Blindfolding is an indicator of the goodness of fit that measures the relevance of constructs in relation to the general theoretical model. For the analysis, the relevance or predictive quality indicator $\left(Q^{2}\right)$ or Stone-Geisser indicator and effect size $\left(f^{2}\right)$ or Cohen indicator are used (Ringle, Silva, and Bido, 2014).

The $Q^{2}$ indicator shows the approximation of the model to what was expected of it and the quality of the model. The values of the $Q^{2}$ indicator need to be greater than zero, and the closer they are to the number one, fewer errors are identified and the model comes closer to reflecting reality (Hair et al., 2014). The $f^{2}$ indicator helps to identify how much each construct influences the model. The values used as a reference for identifying the $f^{2}$ are $0.02,0.15$ and 0.35 , which are considered small, medium and large, respectively (Hair et al., 2014). Table 4 shows that both the $Q^{2}$ and $f^{2}$ values indicate the accuracy of the proposed model and that all the constructs are important to the general fit of the model.

\subsection{Path analysis and test of the hypotheses}

The bootstrapping analysis of student's $T$-test of the 19 proposed paths identified eight relationships with results that are not significant $(\phi$-value $>5 \%)$. Of these relationships that

\begin{tabular}{lcccc}
\hline Constructs & AVE & Composed reliability & $R^{2}$ & Cronbach's alpha \\
\hline Antecedent word of mouth & 0.660 & 0.939 & & 0.926 \\
Word of mouth & 0.808 & 0.927 & 0.730 & 0.881 \\
Trust & 0.718 & 0.884 & & 0.808 \\
Site creativity & 0.760 & 0.927 & 0.895 \\
Online brand image & 0.805 & 0.943 & 0.919 \\
Repurchase intention & 0.777 & 0.913 & 0.773 & 0.856 \\
Declared loyalty & 0.694 & 0.931 & 0.642 & 0.855 \\
Site popularity & 0.634 & 0.896 & 0.673 & 0.907 \\
General satisfaction & 0.783 & 0.935 & & 0.836 \\
Discount rate attractiveness & 0.670 & 0.890 & 0.828 \\
Design (service quality) & 0.744 & 0.897 & 0.904 \\
Fulfillment (service quality) & 0.839 & 0.940 & & 0.887 \\
Security (service quality) & 0.816 & 0.930 & & 0.854 \\
Service (service quality) & 0.774 & 0.911 & & \\
Source(s): Elaborated by the authors based on the SmartPLS output & &
\end{tabular}

Source(s): Elaborated by the authors based on the SmartPLS output
Table 2 .
Convergent validity of the indicators 


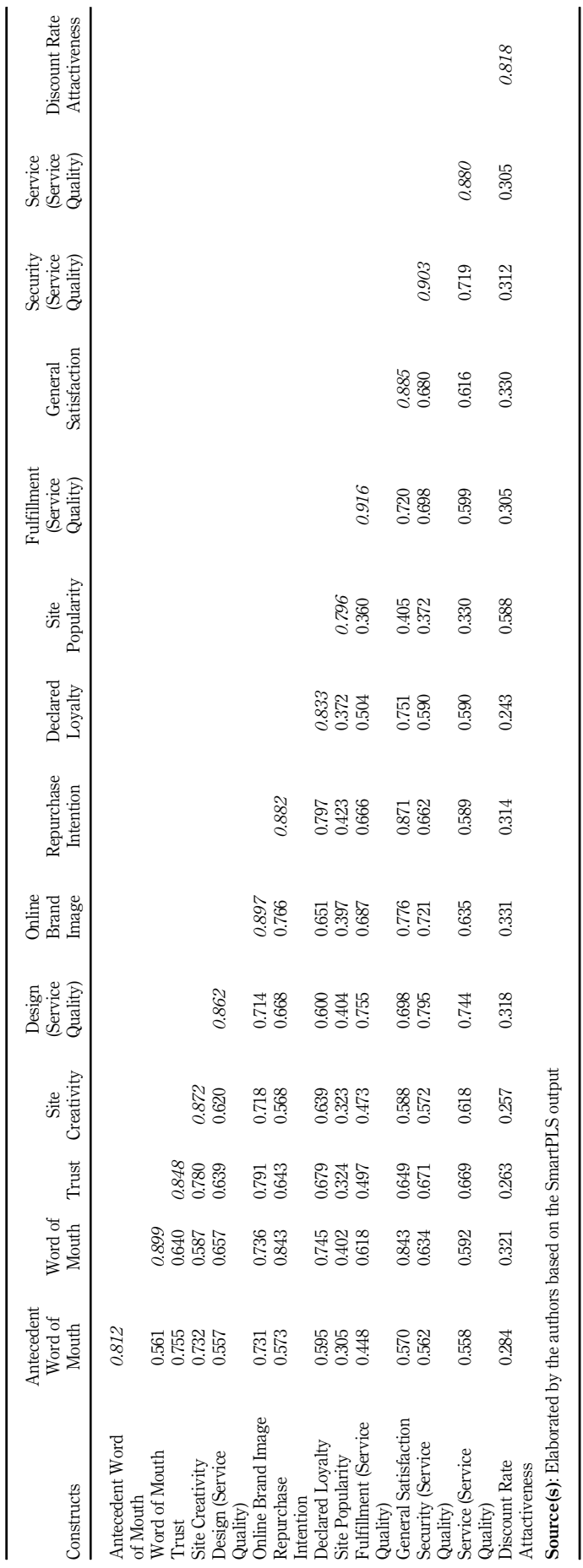

Determinants of loyalty to online group buying

221

Table 3. Discriminant validity of the constructs 
REGE 27,3

\section{2}

Table 4.

Values of the predictive validity $\left(Q^{2}\right)$ or StoneGeisser indicator and the effect size $\left(f^{2}\right)$ or Cohen indicator are considered nonsignificant, three are paths concerning the construct creativity to positive WOM, to repurchase intention and to general satisfaction. Two nonsignificant relationships were the paths of service quality to positive WOM and to declared loyalty. Another nonsignificant path was antecedent WOM to general satisfaction. The path of trust to general satisfaction also appeared to be nonsignificant and the last path that had a nonsignificant outcome was attractiveness of discount rates to general satisfaction. All the other paths were considered significant.

Table 5 shows the overview of the tests of the hypotheses following the statistical analyses, with descriptions of the paths, the $T$ indicators of the bootstrapping and the results of these paths in terms of significance.

Figure 2, below, shows the paths and the confirmation status (s.) or rejection (n.s.) of the hypotheses, as well as the $R^{2}$ indicators of the constructs. The nonsignificant paths and,

\begin{tabular}{lcc}
\hline Construct & $\left(Q^{2}\right)$ & $\left(f^{2}\right)$ \\
\hline Antecedent word of mouth antecedente & 0.561 & 0.561 \\
Positive word of mouth mmotrustuthpositivo & 0.557 & 0.582 \\
Trust & 0.423 & 0.423 \\
Creativity & 0.586 & 0.586 \\
Online brand image & 0.658 & 0.658 \\
Repurchase intent intentionntenção de recompra & 0.593 & 0.532 \\
Declared loyalty declarada & 0.428 & 0.569 \\
Popularity & 0.441 & 0.441 \\
Service quality & 0.548 & 0.548 \\
General satisfaction & 0.512 & 0.621 \\
Attractiveness of discount rate & 0.443 & 0.443 \\
Source(s): Prepared by the authors & & \\
\hline
\end{tabular}

\begin{tabular}{lllll}
\hline Hypothesis & Path & $t$-test & Significance & Status \\
\hline H1 & Attractiveness of discount rate $\rightarrow$ General satisfaction & 0.35 & n. s. & Rejected \\
H2 & Service quality $\rightarrow$ General satisfaction & 8.76 & $p<0.001$ & Confirmed \\
H3a & Service quality $\rightarrow$ Declared loyalty & 0.57 & n. s. & Rejected \\
H3b & Service quality $\rightarrow$ Repurchase intention & 2.30 & $p<0.05$ & Confirmed \\
H3c & Service quality $\rightarrow$ Positive word of mouth & 1.53 & n. s. & Rejected \\
H4 & Popularity $\rightarrow$ General satisfaction & 2.17 & $p<0.05$ & Confirmed \\
H5 & Online brand image $\rightarrow$ General satisfaction & 8.74 & $p<0.001$ & Confirmed \\
H6 & Antecedent word of mouth $\rightarrow$ General satisfaction & 0.61 & n. s. & Rejected \\
H7 & Trust $\rightarrow$ General satisfaction & 0.53 & n. s. & Rejected \\
H8a & Trust $\rightarrow$ Declared loyalty & 4.46 & $p<0.001$ & Confirmed \\
H8b & Trust $\rightarrow$ Repurchase intention & 2.38 & $p<0.05$ & Confirmed \\
H8c & Trust $\rightarrow$ Positive word of mouth & 2.39 & $p<0.05$ & Confirmed \\
H9 & Creativity $\rightarrow$ General satisfaction & 0.16 & n. s. & Rejected \\
H10a & Creativity $\rightarrow$ Declared loyalty & 3.81 & $p<0.001$ & Confirmed \\
H10b & Creativity $\rightarrow$ Repurchase intention & 0.28 & n. s. & Rejected \\
H10c & Creativity $\rightarrow$ Positive word of mouth & 1.50 & n. s. & Rejected \\
H11a & General satisfaction $\rightarrow$ Declared loyalty & 13.06 & $p<0.001$ & Confirmed \\
H11b & General satisfaction $\rightarrow$ Repurchase intention & 20.33 & $p<0.001$ & Confirmed \\
H11c & General satisfaction $\rightarrow$ Positive word of mouth & 17.03 & $p<0.001$ & Confirmed \\
Source(s): Elaborated by the authors & & & \\
\hline
\end{tabular}

Table 5.

Overview of the hypothesis tests 


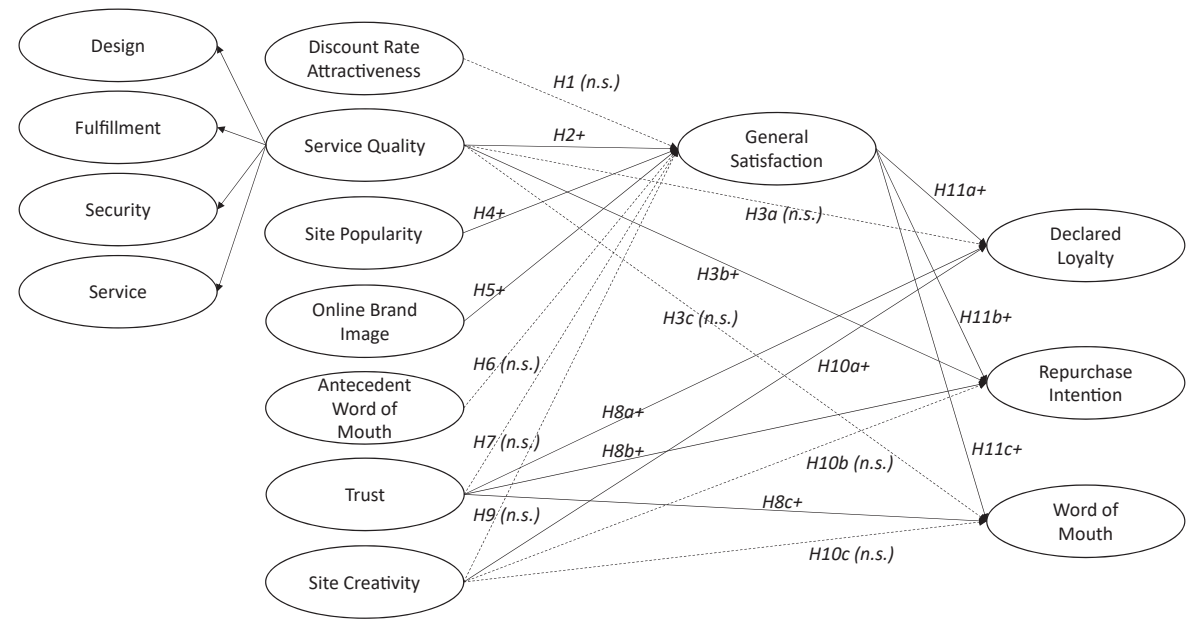

Source(s): Elaborated by the authors
Determinants of loyalty to online group buying

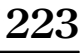

Figure 2.

Theoretical model with analysis of the hypotheses

therefore, those that reject the hypotheses proposed in the theoretical model of this study, were dotted to represent the statistical weakness of the path.

\section{Discussion}

The discussion of the results was constructed on the initial theoretical model to enable an analysis of the significant and confirmed relationships between the constructs and the nonsignificant and rejected relationships and identify possible causes of the rejection of these paths proposed in the present study. In all, this study presented and tested 11 hypotheses.

Regarding the aspects of general satisfaction of consumers of collective purchasing sites, after the tests were conducted in the sample, a positive relationship was observed between this construct and service quality (H2), popularity of the site (H4) and online brand image of the group buying site (H5). No relationship was found between the general satisfaction of the consumer and attractiveness of discount rates (H1), antecedents of WOM (H6), trust (H7) and creativity of collective purchasing sites (H9).

Hypothesis $\mathrm{H} 2$ confirmed the theory that service quality is also a predictor of general satisfaction (Parasuraman, Zeithaml, \& Malhotra, 2006; Zhang et al., 2013) in the online group buying segment. H4 was confirmed, which indicates that popularity affects general satisfaction (Zhang et al., 2013), as was H5, confirming that online brand image influences the general satisfaction of consumers among the group surveyed $(\mathrm{Ku}, 2012)$.

H1 was not confirmed, showing that the attractiveness of discount rates had no direct relationship with general satisfaction. As the analysis was conducted concerning the variable after the purchase, its effect could have been subsumed by the force of the other constructs that were tested, which showed a greater effect in the context of postpurchase evaluation. The attractiveness of discount rates may be a variable of interest to consumers only at the beginning of the purchase process to attract them to the site.

H6 was not confirmed, demonstrating that, in the sample, there is no relationship between antecedents of WOM and the general satisfaction of consumers of group buying sites in Brazil, contradicting the study of $\mathrm{Ku}$ (2012). An explanation for this result is that the Brazilian 
REGE 27,3

group buying process differs from the models of other countries, which generates a relationship network, with discussions of the product or service through the site itself prior to the purchase. In Brazil, decisions are made by the consumer through a more individual process, with little or no interaction among buyers on the group buying site. It is important, though, to admit that Brazilian consumers can access relevant information about group buying sites through other sites where other consumers post their complaints, such as Reclame Aqui.

Hypothesis $\mathrm{H} 7$ was not confirmed, meaning that consumer's trust in the group buying site did not affect general satisfaction, which is not in line with the findings of Shiau and Luo (2012). Service quality was one of the strongest predictors. The scale items refer to recent, specific and concrete transactions. An overall trust in group buying sites may be considered more abstract and distant, thus less in line with a specific transaction. If this is the case, it shows that consumer's trust does not guarantee satisfaction on its own. These group buyers must experience the site and assess its products and services in short term in order to be satisfied.

Hypothesis H9 was not confirmed, showing that creativity may be a great tool for communication, advertising and stimulating purchases (Andrews \& Smith, 1996; Shiau \& Luo, 2012), but does not necessarily guarantee consumer satisfaction, at least in the sample of this study. The hypothesis may not have been confirmed due to the creativity of the site variable having more influence on the consumer's decision to purchase than on satisfaction, which occurs after the purchase experience.

The positive relationship between declared loyalty and trust (H8a), creativity of the site (H10a) and general satisfaction (H11a) was confirmed. No direct and significant relationship was found between declared loyalty and service quality (H3a). Nevertheless, studies of quality in other online contexts have tested and confirmed general satisfaction as a mediator between quality and loyalty (Kaura, Durga Prasad, \& Sharma, 2015).

Hypothesis H8a was confirmed, demonstrating that trust is associated with declared loyalty, reinforcing the findings of previous studies (Shiau \& Luo, 2012; Santos \& Fernandes, 2005; Matos \& Henrique, 2006; Terres, Santos, \& Alves, 2009) and extending them into the group buying domain. H10a was also accepted, confirming that creativity affects declared loyalty (Andrews \& Smith, 1996). H11a was also confirmed, showing that general satisfaction is associated with declared loyalty (Parasuraman, Zeithaml, \& Malhotra, 2006).

Hypothesis H3a was not confirmed, showing that service quality affected repurchase intention directly in group buying (Parasuraman, Zeithaml, \& Malhotra, 2006; Zhang et al. 2013), but does not influence declared loyalty. In this case, the same argument presented for the nonsignificant direct relationship between service quality and declared loyalty is valid but mediated by satisfaction in accordance with other studies in the online context.

The positive relationship between repurchase intention and service quality (H3b), trust (H8b) and general satisfaction (H11b) was also confirmed in this sample.

Hypothesis H3b was confirmed, showing that service quality is also associated with repurchase intention (Parasuraman, Zeithaml, \& Malhotra, 2006; Zhang et al. 2013) in the group buying domain. H8b was confirmed, demonstrating that the consumer's trust affects repurchase intention (Shiau \& Luo, 2012; Santos \& Fernandes, 2005; Matos \& Henrique, 2006; Terres, Santos, \& Alves, 2009), as was H11b, that general satisfaction is associated with repurchase intention (Parasuraman, Zeithaml, \& Malhotra, 2006; Zhang et al., 2013).

Hypothesis H10b was not confirmed, demonstrating that creativity did not affect repurchase intention among the group buyers surveyed. Creativity may be an important element in marketing strategy for decisions to purchase (Andrews \& Smith, 1996; Shalley, Gilson, \& Blum, 2000), but proved not to be an element that influenced repurchase intention.

The positive relationship between positive WOM and trust (H8c) and general satisfaction (H11c) was confirmed. Relationships between this construct with service quality (H3c) and creativity of the site (H10c) were not confirmed. As shown in previous hypotheses, such as 
WOM and other dimensions of loyalty (Dick \& Basu, 1994), the relationship may be due to the mediation of general satisfaction. Meanwhile, in the case of creativity, this element of marketing communications can facilitate other stages of the consumer's cognitive processing but does not affect positive WOM in the context of group buying.

Finally, Hypothesis H8c was confirmed, demonstrating that the consumer's trust in this sample is also associated with positive WOM (SHIAU; LUO, 2012) in the group buying domain, as was H11c, showing that general satisfaction affects positive WOM (Parasuraman, Zeithaml \& Malhotra, 2006; Zhang et al., 2013).

\section{Conclusion}

This study contributes to the literature on marketing and online consumer behavior, more specifically in the context of group buying, by identifying the factors that affect consumer satisfaction and loyalty to group buying websites. It should be remembered that the Brazilian context differs greatly from the models traditionally adopted and widely researched in countries such as the United States, China, Taiwan, Germany, Russia and Canada, but it is also a potential field for future research.

Based on prior theory and other studies, the authors developed a model aiming to cover several relevant aspects of online group buying sites and consumer satisfaction and loyalty. The final model aggregated constructs ranging from utilitarian (attractiveness of discount rate) to more hedonic variables (creativity of the site), from concrete operational service aspects to more abstract brand image perceptions and proposed 11 hypotheses to be tested considering seven antecedents of satisfaction and loyalty. A good part of the proposed relations had already been tested in other studies. However, to our knowledge, this is the broader model developed and tested with all the paths competing with each other to explain satisfaction and loyalty.

The proposed model identifies the constructs that influence satisfaction and loyalty to group buying sites, namely, service quality, popularity, online brand image, trust and creativity. General satisfaction is affected by service quality, popularity and online brand image. Attitudinal loyalty is influenced by service quality, trust and creativity of the site, as well as by general satisfaction, which has a direct influence. This is a robust model in terms of its predictive power, given that the $R^{2}$ indicators have values ranging between 60 and $80 \%$, which are considered strong (Ringle, Silva, \& Bido, 2014).

From a managerial perspective, marketing managers should face price perception in group buying sites as a cosmetic variable, meaning consumers face it as a quality criterion rather than competitive itself. Given the fact that pricing can be accessed by other departments, marketers should focus on providing service excellence. Also, they should make good use and extra effort to broaden group buying site's popularity and online brand image to improve users' satisfaction and thus loyalty.

Much is said about dissatisfaction and high rates of complaints regarding group buying (Lin, Yen, Wang, \& Yeh, 2018). This shows the need for more studies that identify the factors that lead to customers' dissatisfaction and an analysis of the weakening of the brand that may exist after collective purchasing campaigns are over.

The new forms and means of communication of companies have had many negative effects on the development of brands and organizations, especially small and micro-sized enterprises. The literature has paid little attention to the effects of these strategies in the long term and it has not been clearly shown whether they can increase turnover when implemented and reduce it soon afterward (Lima \& Porto, 2012).

Another suggestion for future studies is to consider other constructs to gauge their influence on purchase behavior on group buying sites, as verified by Reck and Basso (2018) and Lim (2019), to test whether online group buying purchase behavior differs from those made on regular shopping sites.
Determinants of loyalty to online group

buying

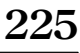


REGE 27,3

\section{References}

Abdeldayem, M. M. (2010). A study of customer satisfaction with online shopping: Evidence from the UAE. International Journal of Advanced Media and Communication, 4(3), 235-257.

Andrews, J., \& Smith, D.C. (1996). Search of the marketing imagination: Factors affecting the creativity of marketing programs for mature products. Journal of Marketing Research, 33(2), 174-187.

Benazzi, J.R., \& Pedra, B.Y. (2011). Compras Coletivas: Uma Análise Exploratória de sua Utilidade para as Empresas Anunciantes. Anais do Simsocial: Simpósio em Tecnologias Digitais e Sociabilidade, UFBA, Salvador, 13-14.

Bruner, G.C. II (2009). Marketing scales handbook. A compilation of multi-item measures for consumer behavior \& advertising research. GCBII Productions, Carbondale, Illinois, USA.

Cedrola, E., \& Memmo, S. (2010). Loyalty marketing and loyalty cards: a study of the Italian market. International Journal of Retail \& Distribution Management, 38(3), 205-225.

Cheung, C.M., Lee, M.K., \& Rabjohn, N. (2008). The impact of electronic word-of-mouth: The adoption of online opinions in online customer communities. Internet Research: Electronic Networking Applications and Policy, 18(3), 229-247.

Chiu, Y.L., Chen, L.J., Du, J., \& Hsu, Y.T. (2018). Studying the relationship between the perceived value of online group-buying websites and customer loyalty: The moderating role of referral rewards. Journal of Business and Industrial Marketing, 33(5), 665-679.

Coulter, K.S., \& Roggeveen, A. (2012). Deal or no deal? How number of buyers, purchase limit, and time-to-expiration impact purchase decisions on group buying websites. Journal of Research in Interactive Marketing, 6(2), 78-95.

Coelho, L.S., Oliveira, R.C., \& Alméri, T.M.O (2013). Crescimento do E-commerce e os problemas que o acompanham: A identificação da oportunidade de Melhoria em uma rede de Comércio eletrônico na visão do cliente. Revista de Administração do UNISAL, 3(3), Campinas, 63-85, Jan/Abr.

Dabholkar, P.A., Thorpe, D.I., \& Rentz, J.O. (1996). A measure of service quality for retail stores: Scale development and validation. Journal of the Academy of Marketing Science, 24(1), 3-16.

Dias, S.E.F., Santos, R.M., Martins, V., \& Isabella, G. (2014). Efeitos das estratégias de marketing de compras coletivas sobre o comportamento impulsivo. Revista Brasileira de Marketing, 12(3).

Dick, A., \& Basu, K. (1994). Customer loyalty: Toward an integrated conceptual framework. Journal of the Academy of Marketing Science, 22(2), 99-113.

Dobni, D., \& Zinkhan, G.M. (1990). In search of brand image: A foundation analysis. Advances in Consumer Research, 17(1), 110-119.

Doney, P.M., \& Cannon, J.P. (1997). An examination of the nature of trust in buyer-seller relationships. Journal of Marketing, 61(2), 35.

E-Bit (2019). WebShoppers, 39a edição. available at: http://www.ebit.com.br/webshoppers (accessed 29 April 2019).

Exame (2018). De groupon a meituan: Com o fim do descontão, como nada o peixe urbano?. available at: https:/exame.abril.com.br/pme/de-groupon-para-meituan-apos-onda-de-descontos-como-nada-opeixe-urbano/ (accessed 2 May 2019). Published: August 22nd.

Frederico, E., Teixeira, N.C., Ghani, S.A.A., \& Andrade, J. (2017). Determinantes da lealdade aos sites de compras coletivas (SCCs). REGE-Revista de Gestão, 24(3), 281-290.

Han, B., \& Kim, M. (2019). Hofstede's collectivistic values and sustainable growth of online group buying. Sustainability, 11(4), 1016.

Hair, J.F., Hult, G.T.M., Ringle, C.M., \& Sarstedt, M. (2014). A primer on partial least squares structural equation modeling (PLS-SEM). Sage Publications, New York, NY, USA.

Hapenciuc, C.V., \& Condratov, I. (2007). Theoretical framework for quality evaluation of tourismrelated websites services. Economy Informatics, 1(4), 52-58. 
Ieva, M., De Canio, F., \& Ziliani, C. (2018). Daily deal shoppers: What drives social couponing?. Journal of Retailing and Consumer Services, 40, 299-303.

Isabella, G., Pozzani, A.I., Chen, V.A., \& Gomes, M.B.P. (2012). Influência dos Anúncios de Desconto sobre o Comportamento dos Consumidores. RAE - Revista de Administração de Empresas, 52(06), 657-671.

Kaura, V., Durga Prasad, C.S., \& Sharma, S. (2015). Service quality, service convenience, price and fairness, customer loyalty, and the mediating role of customer satisfaction. International Journal of Bank Marketing, 33(4), 404-422.

Ku, E.C.S. (2012). Beyond price: How does trust encourage online group's buying intention? Internet Research, 22(05), 569-590.

Kuenzel, S., \& Halliday, S.V. (2008). Investigating antecedents and consequences of brand identification. Journal of Product \& Brand Management, 17(5), 293-304.

Lam, S.Y., \& Mukherjee, A. (2005). The effects of merchandise coordination and juxtaposition on consumers' product evaluation and purchase intention in store-based retailing. Journal of Retailing, 81(3), 231-250.

Laran, J.A., \& Espinoza, F.S. (2004). Consumidores satisfeitos, e então? Analisando a satisfação como antecedente da lealdade. Revista de Administração Contemporânea, 8(2), 51-70.

Lim, W.M. (2019). An equity theory perspective of online group buying. Journal of Retailing and Consumer Services.

Lima, M.I.C., \& Porto, R.B. (2012). Efeito prolongado das estratégias de comunicação de marketing e dos indicadores setoriais no faturamento de bares. REMARK - Revista Brasileira de Marketing, 11(03), 54-75, Set./Dez.

Lin, H.H., Yen, W.C., Wang, Y.S., \& Yeh, Y.M. (2018). Investigating consumer responses to online group buying service failures: The moderating effects of seller offering type. Internet Research, 28(4), 965-987.

Liao, S.H., Chu, P.H., Chen, Y.J., \& Chang, C.C. (2012). Mining customer knowledge for exploring online Group Buying behavior. Expert Systems with Applications (February), 3708-3716.

Lopes, E.L., Hernandez, J.M.D.C., \& Nohara J.J. (2009). Escalas Concorrentes para a Mensuração da Qualidade Percebida: Uma Comparação entre a Servqual e a RSQ. Revista de administração de empresas, 49(4) 401-416, October.

Lopes, E.L., De Lamônica Freire, Bandeira, O., \& Lopes, E.H. (2019). Competing scales for measuring perceived quality in the electronic retail industry: A comparison between ES-qual and E-TailQ. Electronic Commerce Research and Applications, 34, 100824.

Luo, X., Andrews, M., Song, Y., \& Aspara, J. (2014). Group-buying deal popularity. Journal of Marketing, 78(2), 20-33.

Matos, C.A., \& Henrique, J.L. (2006). Balanço do Conhecimento em Marketing: Uma Meta-Análise dos Resultados Empíricos dos Antecedentes e Consequentes da Satisfação e da Lealdade. 30 Encontro da ANPAD, Salvador.

Mendes Filho, L., Jorge, V.A., \& De Sena Júnior, O.B. (2016). Percepção do uso de sites de compras coletivas ao adquirir cupons de serviços turísticos. Revista Brasileira de Pesquisa em Turismo, 10(3), 574-593.

Mercado \& Consumo Peixe Urbano consolida mudanças e volta a crescer. available at: https:// www.mercadoeconsumo.com.br/2019/02/12/peixe-urbano-consolida-mudancas-e-volta-a-crescer/ (accessed 2 May 2019).

Odekerken-Schröder, G., De Wulf, K., \& Schumacher, P. (2003). Strengthening outcomes of retailerconsumer relationships: The dual impact of relationship marketing tactics and consumer personality. Journal of Business Research, 56(3), 177-190.

Oliver, R. (1999). A whence consumer loyalty?. Journal of Marketing, 63, 33-44.

Oliver, R. (1997). Satisfaction: A behavioral perspective on the consumer, McGraw- Hill/Irwin, Boston, MA.

Determinants of loyalty to online group buying

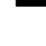


REGE 27,3

Parasuraman, A., Zeithaml, V.A., \& Berry, L.L.S. (1988). A multiple.item, scale for measuring consumer perceptions of service quality. Journal of Retailing, 64, 12-40.

Parasuraman, A., Zeithaml, V.A., \& Malhotra, A.E.S.Q. (2006). A multiple-item scale for assessing eletronic service quality. Journal of Service Research, 7(3), 213-233.

Reck, D., \& Basso, K. (2018). Comportamento de compra por impulso em sites de compras coletivas/ impulsive purchase behavior in collective shopping sites. Revista Gestão Organizacional, 11(1).

Ringle, C.M., Silva, D., \& Bido, D. (2014). Modelagem de Equações estruturais com utilização do SmartPLS. REMark - Revista Brasileira de Marketing/ BJM - Brazilian Journal of Marketing, 13(2).

Santos, C.P., \& Fernandes, D.V.H. (2005). A Recuperaçãa de Serviços como Ferramenta de Relacionamento: seu Impacto na Confiança e Lealdade dos Clientes. Encontro Anual da ANPAD, Brasília.

Shalley, C.E., Gilson, L.L., \& Blum, T.C. (2000). Matching creativity requirements and the work environment: Effects on satisfaction and intentions to leave. Academy of Management Journal, 43(2), 215-223.

Shiau, W., \& Luo, M.M. (2012). Factors affecting online group buying intention and satisfaction: A social exchange theory perspective. Computers in Human Behavior, 28, 2431-2444.

Srinivasan, S.S., Anderson, R., \& Ponnavolu, K. (2002). Customer loyalty in E-commerce: An exploration of its antecedents and consequences. Journal of Retailing, 78, 41-50.

Terres, M.S., Santos, C.P., \& Alves, D.A. (2009). Desenvolvimento de uma Escala para Mensuração da Confiança Cognitiva, A fetiva e Comportamental e Verificação de seus Impactos na Lealdade. XXXIII Encontro da Anpad, São Paulo.

Trusov, M., Bucklin, R.E., \& Pauwels, K. (2009). Effects of word-of-mouth versus traditional marketing: Findings from an internet social networking site. Journal of Marketing, 73, 90-102.

Wolfinbarger, M., \& Gilly, M.C. (2003). eTailQ: dimensionalizing, measuring and predicting etail quality. Journal of Retailing, 79, 183-198.

Yeh, Y.S., \& Li, Y.M. (2009). Building trust in m-commerce: contributions from quality and satisfaction. Online Information Review, 33(6), 1066-1086.

Zeithaml, V.A., Berry L.L., \& Parasuraman, A. (1996). The behavioral consequences of service quality. Journal of Marketing, 60, 31-46.

Zhou, J., \& George, J.M. (2001). When job dissatisfaction leads to creativity: Encouraging the expression of voice. Academy of Management Journal, 44(4), 682-696.

Zhang, Z., Zhang, Z., Wang, F., Law, R., \& Li, D. (2013). Factors influencing the effectiveness of online group buying in the restaurant industry. International Journal of Hospitality Management, 35, 237-245.

\section{Further reading}

E-Bit (2014). WebShoppers, $29^{\mathrm{a}}$ edição. available at: http://www.ebit.com.br/webshoppers (accessed 7 April 2014).

\section{Corresponding author}

Otávio Bandeira De Lamônica Freire can be contacted at: otfreire@usp.br

Associate Editor: Adriana Marotti de Mello

For instructions on how to order reprints of this article, please visit our website:

www.emeraldgrouppublishing.com/licensing/reprints.htm

Or contact us for further details: permissions@emeraldinsight.com 